\title{
Distribution AND DisPERSAl OF DECAPOD CRUSTACEAN LARVAE AND OTHER ZOOPLANKTON IN THE ITAMARACÁ ESTUARINE SYSTEM, BRAZIL
}

\author{
RALF SCHWAMBORN ${ }^{1,3}$ \\ SIGRID NEUMANN-LEITÃ ${ }^{2}$ \\ TAMARA DE ALMEIDA E SILVA ${ }^{2}$ \\ ANDREA PINTO SILVA ${ }^{2}$ \\ WERNER EKAU ${ }^{1}$ \\ ULRICH SAINT-PAUL ${ }^{1}$
}

1) Center for Tropical Marine Ecology, Bremen, Germany

2) Federal University of Pernambuco, Recife, Brazil

3) Present address: Federal University of Pernambuco, Recife, Brazil

\begin{abstract}
A zooplankton survey was carried out from February 1995 to May 1996, to assess the distribution and dispersal of decapod crustacean larvae in the Itamaracá estuarine system (IES). Sampling was performed during diurnal low tides, using a $300 \mu \mathrm{m}$-mesh plankton net with $60 \mathrm{~cm}$ mouth opening diameter. Forty-nine taxa were registered, including 29 decapod crustacean taxa. The most abundant taxa were copepods, brachyuran zoeae, and cirripedian nauplii, followed by adult Lucifer faxoni, chaetognaths, appendicularians, fish eggs, gastropods, and upogebiid zoeae. High overall variability as well as the positive correlations between abundances of many taxa at IES were probably due to spatial aggregation of zooplankton in convergence zones. The brachyuran zoeae belonged to the families Ocypodidae, Grapsidae, Xanthidae and Leucosiidae. Zoeae of the mangrove crab Ucides cordatus and of fiddler crabs (Uca spp.), both with adults dwelling in the estuary, were retained in the estuarine plumes rather than exported to the shelf. Xanthid and grapsid zoeae were found in the estuarine plume and at nearshore shelf stations, but in exponentially declining abundance towards the shelf. These results indicate that a concentration of brachyuran zoeae occurs in the estuarine plumes at low tide. Most zoeae are retained inside the plumes, while only few individuals are exported to the continental shelf, probably by active dispersal mechanisms. The decrease in larval abundance from ebb to subsequent flood tides observed at the estuarine inlets in previous studies may thus not be due to export to the shelf only, but may also be related to processes occurring inside the estuarine plumes.
\end{abstract}

Keywords: Tropical Zooplankton, Mangroves, Seagrass, Decapod Crustacean Larvae

\section{RESUMO}

Amostragens quantitativas de plâncton foram desenvolvidas no sistema estuarino de Itamaracá durante baixa-mares diurnas de fevereiro de 1995 a maio de 1996. Utilizou-se uma rede de plâncton de $300 \mu \mathrm{m}$ de abertura de malha e $60 \mathrm{~cm}$ de diâmetro de boca. Foram registrados 49 taxa, inclusive 29 taxa de Decapoda. Os taxa mais abundantes foram Copepoda, zoeas de Brachyura, náuplios de Cirripedia, adultos de Lucifer faxoni, Chaetognatha, Appendicularia, ovos de peixe, Gastropoda, e zoeas de Upogebiidae. As zoeas de Brachyura examinadas ( $\mathrm{N}=265)$ pertenceram ás famílias Ocypodidae, Grapsidae, Xanthidae e Leucosiidae. Larvas do caranguejo-uçá (Ucides cordatus) e de caranguejos chama-maré (Uca spp.), foram encontrados somente na área estuarina, indicando que não houve exportação de larvas destes grupos do estuário para a plataforma continental. Zoeas de Xanthidae e

Tropical Oceanography, Recife, v. 29, n. 1, p. 1-18, 2001. 
Grapsidae foram encontradas nas plumas estuarinas e na plataforma, porém em numero inferior. Análise de agrupamento e MDS (escala multidimensional), baseados em dados de abundância, não demonstraram nenhum padrão claro de agrupamento das estações ou dos taxa, indicando a existência de uma comunidade relativamente homogênea. Análise de correlação realizada com dados $\log _{10}(\mathrm{x}+1)$ transformados de 19 taxa mostrou 39 correlações significantes entre os grupos. A alta variabilidade geral dos dados, tanto como a ocorrência de correlações positivas entre as abundâncias de muitos grupos na área de Itamaracá provavelmente são o resultado da agregação de macrozooplâncton em áreas de convergência.

Palavras chave: Zooplâncton tropical, manguezal; larvas de Curstáceo Decapoda

\section{INTRODUCTION}

Zooplankton is an important intermediate component in estuarine food webs, acting as a trophic link between small particles (e.g. detritus and microalgae) and planktivorous fishes. On the other hand, commercially important fish and invertebrate species produce larvae, which are part of the zooplankton. In spite of the great importance, relatively little work has been done on the zooplankton of mangrove habitats (Robertson and Blaber, 1992). Several dynamic processes have already been studied in mangrove plankton (Robertson and Alongi, 1992; Schwamborn and Saint-Paul, 1996). Already before the start of this study, there was a large body of knowledge about the zooplankton of the Itamaracá estuarine system, which is one of the most intensively studied water bodies in Brazil (Paranaguá and Eskinazi-Leça, 1985; Neumann-Leitão, 1995; Neumann-Leitão et al., 1996, Schwamborn and Neumann-Leitão, 2000). Torbohm-Albrecht (1995) showed a large spatial variability in the community structure of decapod crustacean larvae in the Santa Cruz Channel. A quantitative approach was used by Wehrenberg (1996), who performed 24-hour plankton sampling at the inlets of the Santa Cruz Channel. This study showed that many decapod crustacean taxa (brachyuran, anomuran and caridean zoeae, as well as adults of Lucifer sp.) were more abundant during ebb than on following flood tide, and were thus quantitatively exported from the Santa Cruz Channel. The question that arose from this study was whether the estuarine decapod larvae that are flushed out of the Santa Cruz Channel are retained inside the estuarine plumes, or exported to the coastal seagrass area and to the continental shelf.

The present study represents an evaluation of possible differences in zooplankton biomass and community structure between the inner estuary, the estuarine plumes, and the seagrass beds, over a twoyear-period. Differences in zooplankton composition between the inner estuary and the coastal seagrass area would allow conclusions regarding a possible hydrological and faunistic separation of these areas. A massive export of decapod larvae from the estuary to the seagrass area should produce a similar community structure in both areas. Another important aspect was to verify, if decapod larvae are exported from the IES to the continental shelf, leading to a large-scale dispersal.

Quantitative plankton sampling was performed at the Itamaracá estuarine system in February and March 1995, and in March, April, and May 1996 (Fig. 1). Mesh size of the plankton net employed was $300 \mu \mathrm{m}$, mouth opening diameter was $60 \mathrm{~cm}$. The net was towed $10 \mathrm{~cm}$ below the surface at three $( \pm 0.8)$ knots for 2 to 3 minutes. All samples were preserved immediately in buffered $4 \%$ formaline. Filtered volume was determined by the use of a calibrated flowmeter (Hydrobios, Kiel). A total of 43 zooplankton samples were taken. Salinity and temperature of surface waters were measured with a conductivity probe at every station.

All samples were taken at diurnal low tides, to assess maximum plankton export from the estuary. Sampling was conducted at six stations to study spatial, lunar and seasonal variability of the zooplankton distribution at the IES (Fig. 1). In 1996, sampling was performed twice a month, alternating sampling at spring (full moon) and neap (crescent) tides. Additionally to this estuarine-

Tropical Oceanography, Recife, v. 29, n. 1, p. 1-18, 2001. 
coastal sampling grid, we sampled at six stations along two transects from the estuarine inlets to the nearshore shelf at spring low tide in March 1995, to assess maximum plankton export from the estuary to the shelf (Fig. 1). During this transect study, shelf stations 31 and 37 were sampled on board RV Victor Hensen (Fig. 1). The nets used on board RV Victor Hensen had the same diameter and mesh size and were towed at a speed (2.5 knots) similar to the sampling in the IES.

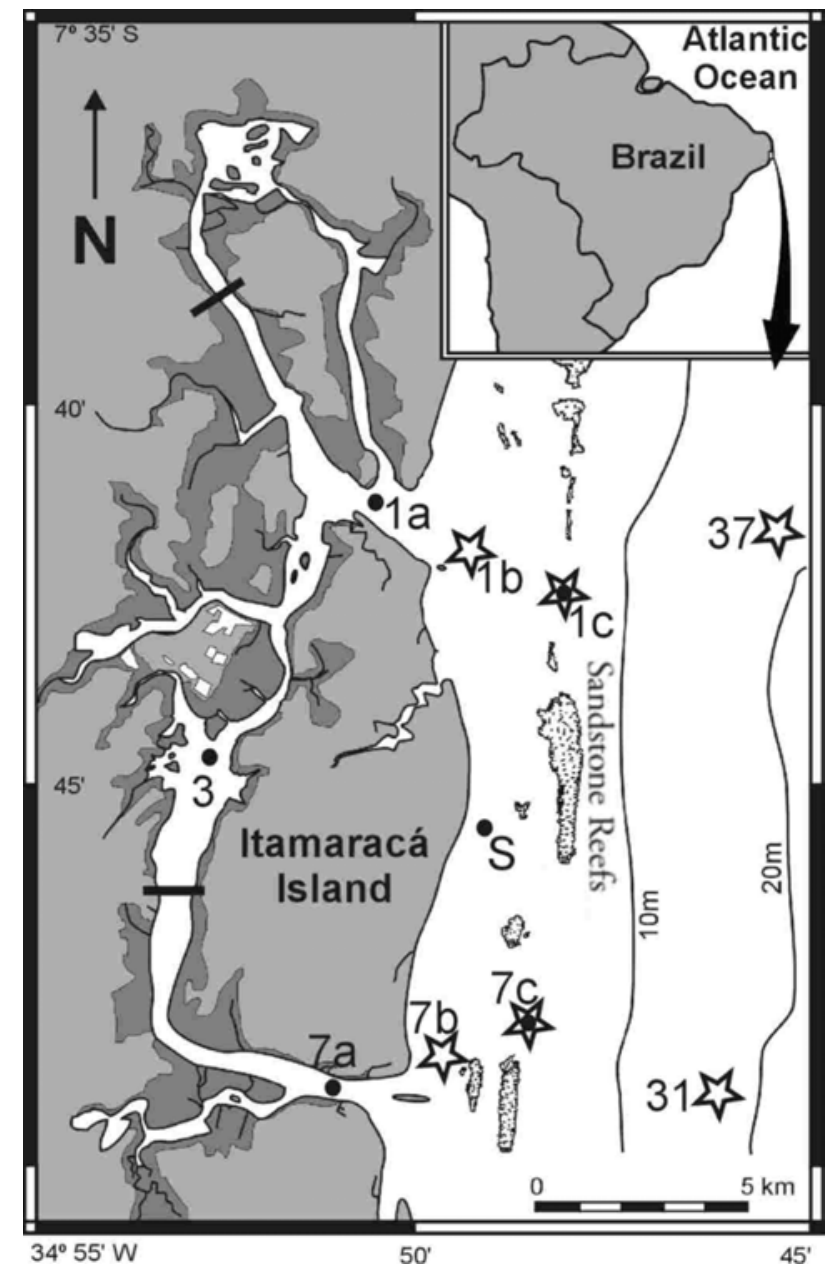

Figure 1 - Station map of the Itamaracá estuarine system. Shaded areas: approximate extent of mangrove forests. Stations marked with full circles were sampled in 1995 and 1996. Stations marked with asterisks were sampled during a survey for larval export in March 1995.

In the laboratory, total biomass of all plankton catches was determined by wet weight. Large debris (e.g. mangrove leaf fragments) found in the samples were weighed separately. To determine the taxonomic composition, subsamples $(0.001 \%$ to $3 \%)$ were taken from the samples with a Wiborg subsampler or with a volumetric subsampling procedure according to Russell and Colman (1931). Subsampling was performed so that generally at least 30 brachyuran zoeae could be sorted per sample.

Tropical Oceanography, Recife, v. 29, n. 1, p. 1-18, 2001. 
Organisms found in the subsamples were sorted and identified to class or order level in taxonomic groups other than Decapoda. Decapod larvae were identified as accurately as possible. Brachyuran zoeae were identified using laboratory-reared reference organisms and available keys and descriptions (Boschi and Scelzo, 1968; Costlow and Bookhout, 1968; Diaz and Ewald, 1968; Warner, 1968; Herrnkind, 1968; Kurata, 1970; Diaz and Costlow, 1972; Rice, 1980; Willems, 1982; Bacardit, 1985a; Bacardit, 1985b; Paula, 1985; Fransozo and Hebling, 1986; Negreiros-Fransozo, 1986; Diaz and Bevilaqua, 1987; Domingues and Hebling, 1989; Negreiros-Fransozo et al., 1989; Montú et al., 1989; Anger et al., 1990; Bakker et al., 1990; Montú et al., 1990; Steiff, 1990; Rodriguez et al., 1992; BrossiGarcia and Rodrigues, 1993; Rieger and Hebling, 1993; Guerao et al., 1995; Paula, 1996). Ovigerous females of nine decapod crustacean species (Petrolisthes armatus, Uca thayeri, U. maracoani, U. leptodactyla, U. burgersi (syn. U. panema), Aratus pisoni, Sesarma rectum, Armases angustipes and Panopeus americanus) were collected in mangrove forests at Itamaracá Island from July 1995 to July 1996 for larval rearing. Larvae from 25 females of these species were reared and examined for morphological comparisons with plankton material. Identification of organisms to class, order, or infraorder level was performed under a binocular microscope, brachyuran zoeae were examined under a compound microscope equipped with a camera clara.

Cluster analysis and multi-dimensional scaling (MDS) were performed with $\log (\mathrm{x}+1)$ transformed abundance data to investigate similarities between stations, and to test for the presence of differences in plankton communities in the dry and rainy seasons. Cluster dendrograms were only accepted, if the groups formed therein agreed with the groups formed in corresponding MDS plots. Cluster analysis and MDS were performed using the computer software package PRIMER, following the procedures recommended by Clarke and Warwick (1994). To test for significant effects of the factors season, tidal amplitude (spring vs neap tide) and station, a Kruskall-Wallis analysis of variance by ranks (K-W ANOVA) was performed for each factor and taxonomic group, without considering interactions between factors (Zar, 1996). This procedure is considered robust against type I errors and avoids several prerequisites necessary for parametric ANOVA (Zar, 1996). To test for significant correlation between abundances of taxa, Pearson's product-moment-correlation analysis (Zar, 1996) was performed with $\log _{10}(x+1)$-transformed abundances of taxa that occurred in at least $30 \%$ percent of the samples.

\section{Salinity and temperature}

During the dry season, salinity was always above 26 PSU at the inner estuary, and above 30 PSU at the channel inlets (Fig. 2). Only in May (rainy season) salinity decreased to minimum values as low as 17.8 PSU at the inner estuary, and to about 21 to $26 \mathrm{PSU}$ at the inlets. Temperature decreased from about $30^{\circ} \mathrm{C}$ in March to a range of 28.5 to $29.0^{\circ} \mathrm{C}$ in May.

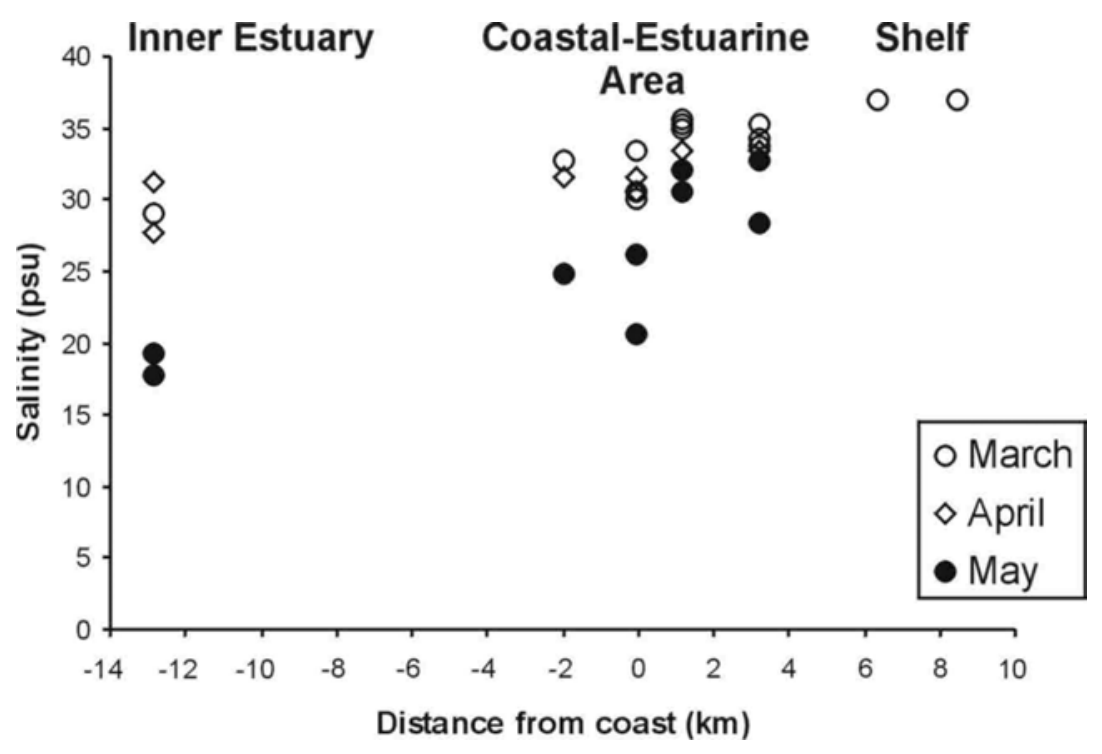


Figure 2 - Changes in the horizontal distribution of surface salinity during the transition from dry (March) to rainy (May) season at the Itamaracá estuarine system, Brazil.

\section{Zooplankton community structure}

Forty-nine zooplankton taxa were registered at the Itamaracá area, including 29 decapod taxa. The most abundant taxa were copepods, brachyuran zoeae, and cirripedian nauplii, followed by adult Lucifer, chaetognaths, appendicularians, fish eggs, gastropods, and upogebiid zoeae. The remaining taxa showed mean densities lower than 10 ind. $\mathrm{m}^{-3}$. Detailed tables of the abundance of all taxonomic groups found at IES are given in Schwamborn (1997).

Cluster analysis and MDS based on abundance data did not show any coherent groups of stations or taxa at the Itamaracá estuarine system. All attempts to form groups of stations or taxa visible both in cluster dendrograms and MDS plots based on abundance data failed. Therefore, the 6 stations regularly sampled at the Itamaracá area could not be grouped by similarities in plankton community structure. It was also not possible to group the samples by season or tidal amplitude consistently by Cluster analysis and MDS. Kruskall-Wallis-ANOVA showed that for several separately analyzed taxonomic groups, there were significant differences between stations, seasons or phases of different tidal amplitude (Table 1). Between-station variability was significant. 0.05 ) for the following taxa: brachyuran zoeae, gastropod larvae, fish eggs, ctenophores, total decapods (larvae and adults), and total meroplankton (larvae of polychaetes, gastropods, cirripedians, decapods, and fishes) (Table 1). Brachyuran zoeae showed significantly. 0.05) higher densities at the estuarine plumes (stations 1a,c, $7 \mathrm{a}, \mathrm{c}$ ) than at the inner estuary (station 3) and at the seagrass area (station S3) (Fig. 3).

Table 1 - Results of the Kruskall-Wallis-ANOVA, based on 37 plankton samples taken in the Itamaracá estuarine system from 1995 to 1996 . Taxonomic groups, that occurred in less than $30 \%$ of the samples, were not considered. Probability of error (p) is given for factors that have a significant effect on abundance. DS: Dry season, RS: rainy season, ST: Spring tide, NT: Neap tide, PZ: protozoeae, n.s.: not significant.

\begin{tabular}{lccc}
\hline Taxonomic group & Season & Tidal amplitude & Station \\
\hline Copepoda & n.s. & n.s. & n.s. \\
Brachyura, zoeae & n.s. & n.s. & 0.027
\end{tabular}

Tropical Oceanography, Recife, v. 29, n. 1, p. 1-18, 2001. 
Caridea, zoeae

Appendicularians

Fish larvae

Gastropoda, larvae

Fish eggs

Chaetognatha

Lucifer faxoni, adults

Cirripedia, nauplii

Hydromedusae

Upogebiidae, zoeae

Anomura, zoeae

Polychaeta

Lucifer sp., mysis

Acetes sp., PZ n.s.

n.s.

$0.0004(\mathrm{DS}<\mathrm{RS})$

n.s.

n.s.

n.s.

n.s.

n.s.

n.s.

$0.0002(\mathrm{DS}<\mathrm{RS})$

n.s.

n.s.

n.s.

n.s.

n.s.

n.s.

$0.027(\mathrm{DS}<\mathrm{RS})$

n.s.

$(0.058, \mathrm{DS}<\mathrm{RS})$ n.s.

n.s.

Ctenophora

Total Biomass

Total Organisms

Total Decapods

Total Meroplankton n.s.

n.s.

n.s.

n.s. $\quad 0.0016$

n.s.

0.001

$0.0005(\mathrm{ST}>\mathrm{NT}) \quad$ n.s.

n.s.

n.s.

$0.00004(\mathrm{NT}>\mathrm{ST}) \quad$ n.s.

n.s.

n.s.

n.s.

n.s.

n.s.

n.s.

n.s.

n.s.

n.s.

n.s.

$0.0007(\mathrm{NT}>\mathrm{ST}) \quad$ n.s.

n.s.

0.0095

n.s. n.s.

n.s.

n.s.

n.s.

0.0074

n.s.

0.0019

Table 2 - Correlation matrix based on 37 samples from the Itamaracá estuarine system. Samples were taken from February to March 1995 and from March to May 1996. Numerical values (fat types) give significant $0.05)$ Pearson's product-moment correlation coefficients for each pair of taxa. The analysis was performed on log-transformed $(\mathrm{x}+1)$ abundance data. ns: not significant; $\mathrm{Z}$ : zoeae; PZ: protozoeae; M: Mysis, N: nauplii.

Tropical Oceanography, Recife, v. 29, n. 1, p. 1-18, 2001. 


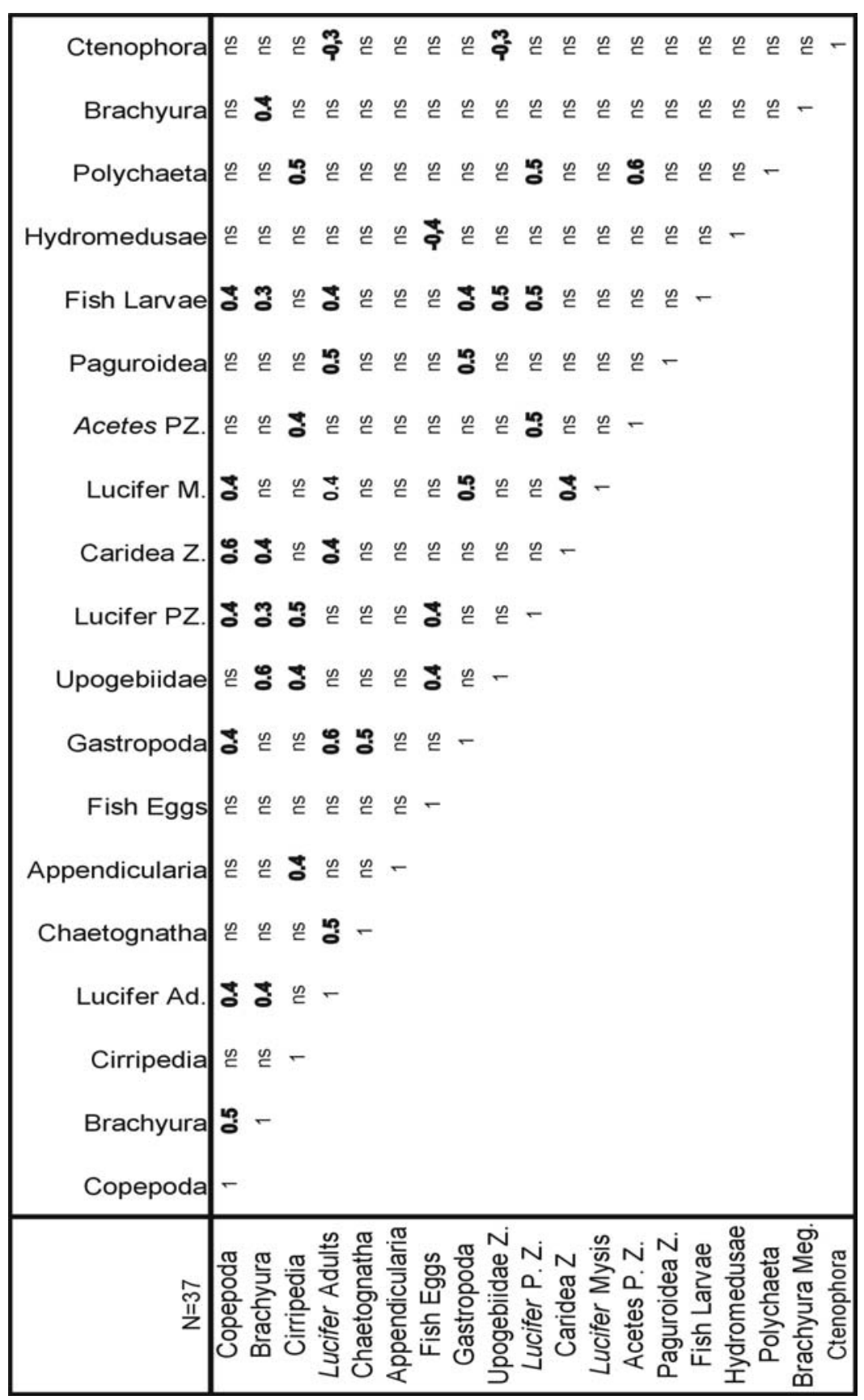

Gastropod larvae where significantly less abundant at the inner estuary than at the northern inlet (Table 1). No fish eggs were found at station 3, and very low densities were registered at station 7a. High densities of fish eggs were found at the northern stations (stations 1a and 1c), but also at the outer southern estuarine plume (station 7c). Seasonality was not detected for the whole zooplankton community (cluster analysis and MDS), but did have a significant effect on the abundance of upogebiid zoeae and fish larvae. Both taxa were less abundant during the dry season than during the rainy season (Table 1). Tidal amplitude showed to have a significant effect on the densities of

Tropical Oceanography, Recife, v. 29, n. 1, p. 1-18, 2001. 
chaetognaths, cirripedian nauplii, and protozoeae of Acetes sp. (Table 1). Chaetognaths occurred in higher densities at spring tide (full moon), while cirripedian nauplii and protozoeae of Acetes sp. occurred at higher densities at neap tide.

Densities of many zooplankton taxa were positively correlated. (Table 2). Of the 39 significant correlations, 36 were positive, and only 3 were negative (Table 2). The 7 taxa that showed at least 5 positive correlations to other taxa were copepods, brachyuran zoeae, cirripedian nauplii, adults and protozoeae of Lucifer, gastropods, and fish larvae (Table 2). Ctenophores and hydromedusae, both gelatinous predators, showed only negative correlations with other taxa.

Table 3 - Abundance of brachyuran zoeae at two transects from Itamaracá Island to the adjacent continental shelf in March 1995. The unidentified Ocypodidae (?) display typical ocypodid appendage setation but do not belong to any ocypodid species whose larvae have been described. unid.: unidentified; Z: Zoea.

\begin{tabular}{|c|c|c|c|c|c|c|}
\hline $\begin{array}{l}\text { Station No. } \\
\text { N examined zoeae }\end{array}$ & $\begin{array}{l}7 \mathrm{~b} \\
43\end{array}$ & $\begin{array}{l}7 \mathrm{c} \\
39\end{array}$ & $\begin{array}{l}31 \\
39\end{array}$ & $\begin{array}{l}1 \mathrm{~b} \\
55\end{array}$ & $\begin{array}{l}1 \mathrm{c} \\
56\end{array}$ & $\begin{array}{l}37 \\
33\end{array}$ \\
\hline & \multicolumn{6}{|c|}{$\begin{array}{l}\text { Abundance } \\
\left(\text { Ind. } \mathrm{m}^{-3}\right)\end{array}$} \\
\hline \multicolumn{7}{|l|}{ Ocypodidae } \\
\hline Uca spp., ZI & 78 & 54 & 0 & 853 & 17 & 0 \\
\hline Uca maracoani, ZI & 8 & 0 & 0 & 71 & 3 & 0 \\
\hline Ucides cordatus, ZI & 0 & 27 & 0 & 1778 & 34 & 0 \\
\hline Ocypodidae (?) unident., ZI & 148 & 0 & 0 & 427 & 3 & 0 \\
\hline Ocypodidae (?) unident., ZII & 31 & 0 & 0 & 0 & 0 & 0 \\
\hline Ocypodidae (?) unident., ZIII-V & 0 & 0 & 19 & 0 & 0 & 8 \\
\hline \multicolumn{7}{|l|}{ Grapsidae } \\
\hline Subfamily Grapsinae, ZI & 8 & 94 & 0 & 640 & 45 & 1 \\
\hline \multicolumn{7}{|l|}{ Xanthidae } \\
\hline Panopeus sp., ZI & 8 & 308 & 4 & 71 & 56 & 9 \\
\hline Menippe sp., ZII-IV & 0 & 27 & 5 & 0 & 0 & 2 \\
\hline Subfamily Pilumninae, ZI-V & 0 & 0 & 2 & 0 & 0 & 4 \\
\hline Xanthidae, unident., ZI & 39 & 13 & 0 & 71 & 0 & 0 \\
\hline Leucosiidae, ZI & 0 & 0 & 0 & 0 & 0 & 1 \\
\hline unidentified Zoeae & 16 & 0 & 2 & 0 & 0 & 0 \\
\hline Total (Ind. $\mathrm{M}^{-3}$ ) & 336 & 523 & 32 & 3911 & 158 & 25 \\
\hline
\end{tabular}

\section{Export and retention of brachyuran zoeae}

A total of 265 brachyuran zoeae sampled at the transects from the estuary to the shelf were dissected and identified. These zoeae belonged to the families Ocypodidae, Grapsidae, Xanthidae and Leucosiidae (Table 3). Four genera (Uca, Ucides, Menippe and Panopeus) could be identified. Specimens belonging to the genera Uca, Ucides, and Panopeus were identified by comparison with laboratory-reared zoeae. The extent of export of the larvae of the mangrove crab Ucides cordatus and of fiddler crabs (Uca spp.) was limited to the Itamaracá estuarine system (Table 3). No zoeae of these taxa were found at shelf stations 31 and 37. Density of zoeae of Uca spp. and Ucides cordatus clearly decreased from the inner estuarine plume towards the outer plume (Fig. 4). The abundances of Uca spp., Uca maracoani, and Ucides cordatus were about 10 to 100 times higher at the middle of the estuarine plumes (stations $1 \mathrm{~b}$ and $7 \mathrm{~b}$ ) than at the outer margin of the plumes (stations 1c and 7c).

Tropical Oceanography, Recife, v. 29, n. 1, p. 1-18, 2001. 


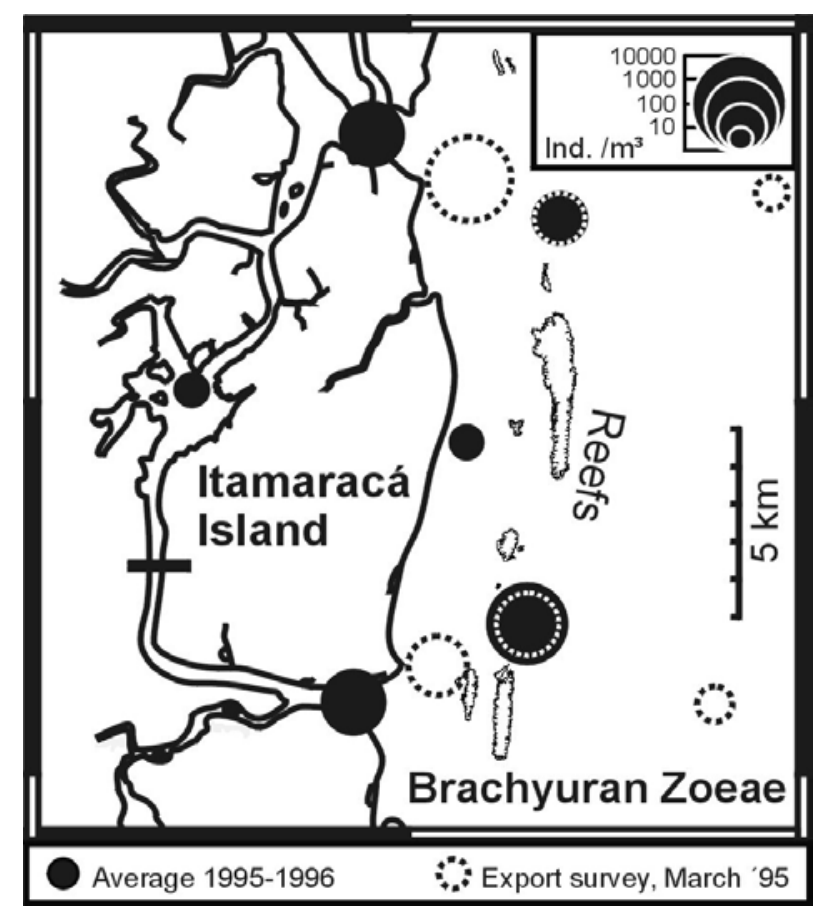

Figure 3 - Abundance of brachyuran zoeae in the Itamaracá estuarine system during diurnal low tides. The diameters of the circles are proportional to log density. Full circles stand for averages over samples taken at 8 sampling dates from 1995 to 1996. Dashed circles stand for abundance values observed during a survey for larval export, conducted in March 1995 off Itamaracá and at the adjacent continental shelf.

Grapsid and xanthid zoeae were found in the estuarine plume and at nearshore shelf stations (Table 3). Zoeae of these two families were detected in very low densities on the shelf, when compared to densities in the estuarine plume (Fig. 4). Densities of xanthid zoeae were 10 to 100 times higher inside the estuarine plume than at nearshore shelf stations.

Unidentified zoeae with „ocypodid“ appendage setation and lateral spines on the abdomen were abundant inside the estuarine plumes and at the nearshore shelf (Table 3). The first two zoeal stages of unidentified „ocypodid“ zoeae were only found inside the estuarine plumes, while advanced stages (zoeae III to V) occurred only at nearshore shelf stations, indicating that these larvae are probably derived from estuarine-coastal parental populations..

At shelf stations (stations 31 and 37), $81 \%$ of brachyuran zoeae found were also present in the estuarine plumes (Table 3). 47\% of the zoeae found at nearshore shelf stations were late „ocypodid“ zoeae, which were much larger in carapace length than the remaining zoeae found at these stations. Those zoeae were thus the brachyuran zoeae with the highest biomass in nearshore shelf waters.

Tropical Oceanography, Recife, v. 29, n. 1, p. 1-18, 2001. 


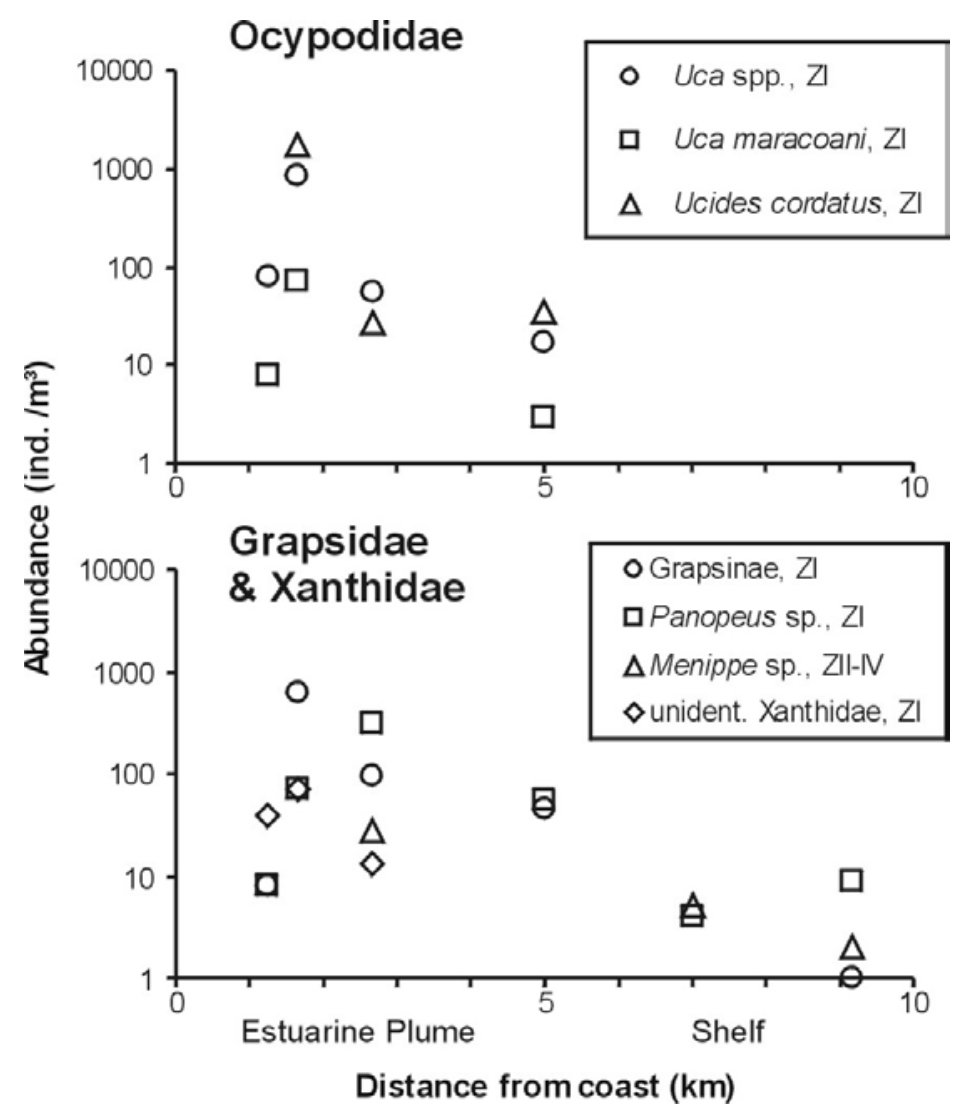

Figure 4 - Distribution of crab zoeae (families Ocypodidae, Grapsidae and Xanthidae) at low tide. Note the logarithmic scale. Samples were taken at two transects from the Itamaracá estuarine system to the nearshore shelf in March 1995. N=6 samples. ZI: First zoeal stage, ZII-IV: zoeal stages II to IV.

\section{DISCUSSION}

One of the striking features of the zooplankton in the Itamaracá estuarine system was its high overall variability in biomass and composition. The high variability between samples is at least partially due to small-scale aggregation caused by transversal convection and consequent formation of spatially limited convergence zones (Ewing, 1950; Zeldis and Jillet, 1982; Shanks, 1983; Jillet and Zeldis, 1985; Shanks, 1985; Kingsford and Choat, 1986; New et al. 1986; New and Dyer, 1987; Pineda, 1991). On the other hand, synchronicity in larval release results in a high temporal variability in meroplankton abundance and composition. For example, one sample taken at station 7c was composed almost exclusively ( $>95 \%$ of individuals) of cirripedian nauplii, which accounts for $82 \%$ of all cirripedian nauplii caught during this study. This high time-space variability in taxonomic composition is probably one cause of the impossibility to group stations at IES or sampling periods together by cluster analysis. These results suggest that variability in zooplankton biomass and composition within stations exceeded the variability between them.

Tropical Oceanography, Recife, v. 29, n. 1, p. 1-18, 2001. 
The large number of significant positive correlations between abundances of several taxa at IES probably reflects the spatial aggregation of zooplankton in convergence zones (Eggleston et al., 1998). However, abundances of gelatinous predators (hydromedusae and ctenophores) were negatively correlated with some zooplankton taxa. These negative correlations may be due to predator avoidance by relatively mobile organisms (e.g. adult Lucifer), by depletion of prey organisms, or simply by differences in spatial distribution. The latter explanation is appropriate for Upogebiidae, which showed peak densities in the seagrass area (Station S3) and at the outer estuarine plumes (stations 1c and 7c), while ctenophores occurred mainly in the inner estuary (station 3) and at the estuarine inlets stations (1a and $7 \mathrm{a})$.

The identification of brachyuran zoeae along the transects form the inlets to the shelf supported the likely assumption that the high abundances of brachyuran zoeae observed at the nearshore shelf off Pernambuco by Schwamborn et al. (1999) were mostly due to the export from mangrove estuaries. Unidentified zoeae with „ocypodid“ appendage setation were abundant inside the estuarine plumes and at the nearshore shelf. Morphological examination of these larvae suggest that they belong to one single species, that has not yet been described. Late stages of those „ocypodids“ (zoea III to zoea V) were only found at the nearshore shelf, where they comprise the highest biomass fraction among brachyuran zoeae. Since the first two stages of these „ocypodids“ were only found inside the estuarine plume, they are probably of estuarine-coastal origin. Dittel and Epifanio (1990) also found a large number of unidentified "ocypodid" zoeae at a small mangrove creek in Costa Rica. Since there are no other ocypodid genera reported for the tropical Atlantic than Ocypode, Uca, and Ucides and the unidentified ,ocypodids“ do not resemble the larvae of any of these genera, the assignment of these larvae to the family Ocypodidae is dubious. These undescribed zoeae presumably belong to a non-ocypodid species, but present an appendage setation that erroneously produces an assignment to this family. Further rearing experiments with brachyuran zoeae are necessary to improve our understanding of tropical zooplankton and available identification keys. Only a very small fraction of the larvae of brachyuran species occurring in northeastern Brazil have already been described.

Export of tropical decapod larvae from mangroves has also been reported elsewhere, but the spatial extent of the export was not determined. Dittel et al. (1991) found that first zoeae of $U c a$ spp. are exported from a tidal mangrove creek in Costa Rica. Export of first stages and subsequent recolonisation of the mangrove ecosystem by megalopae was also documented for a Brazilian estuary by Schwamborn and Bonecker (1996). At the Itamaracá estuarine system, 24 hour-sampling at the estuarine inlets (stations 1a and 7a) during the dry season showed that an export of brachyuran zoeae took place (Wehrenberg, 1996). Densities of brachyuran zoeae were higher at flood than at ebb tides, indicating a net export. Overall export from the estuarine inlets was calculated as $1.5 \times 10^{8}$ zoeae per day (Wehrenberg, 1996). However, the spatial extent of export was not determined. 24-hour sampling at estuarine inlets does not provide information on whether the organisms are actually exported to the shelf or retained in the estuarine plumes. Based on the study of Wehrenberg (1996), the plankton sampling at the IES presented herein had been conceived to assess the spatial extent of export at low tide, combined with a survey of seasonal and between-year variability. The present results show that brachyuran zoeae are mainly concentrated in the estuarine plumes. Abundances of these zoeae were significantly ( $=0.05$ ) higher at the estuarine plumes than at the inner estuary and at the seagrass area. Estuarine crabs usually spawn at high tide, leading to a subsequent transport to estuarine plumes at low tide (Bergin, 1981; Christy, 1982; Wolcott and Wolcott, 1982; Anger et al., 1994). These larvae may be retained inside the estuarine plumes and re-imported to the estuary at high tide (Chen et al., 1997).

But, if most brachyuran zoeae are concentrated inside the estuarine plumes, and not exported, how can there be so much less zoeae during flood than during ebb tide at the inlets, as shown by Wehrenberg (1996) at IES and by other authors (Dittel and Epifanio, 1990; Dittel et al., 1991; Schwamborn and Bonecker, 1996; Freire, 1998) in diverse mangrove estuaries? Two explanations for that apparent contradiction are possible: the first rationale is that zoeal densities are higher during ebb because of a depletion of the zoeal population inside the estuarine plumes by mortality (e.g. due to

Tropical Oceanography, Recife, v. 29, n. 1, p. 1-18, 2001. 
predation and starvation). Additional loss would be caused by a small (but significant) export to adjacent shelf waters. Predation on brachyuran zoeae by abundant planktivorous fishes (Börner, 1994) was already documented at IES (Vasconcelos, 1979; Vasconcelos, 1980; Vasconcelos et al., 1984) and elsewhere (Morgan, 1990). Export to shelf waters is suggested by high abundances of brachyuran zoeae at the nearshore shelf, as compared with offshore stations (Schwamborn et al., 1999). The other rationale is that more zoeae are found at ebb than at flood tide due to tidally rhythmic vertical migration. Plankton sampling in estuarine inlets was generally conducted at or near the surface (Dittel and Epifanio, 1990; Dittel et al., 1991; Schwamborn and Bonecker, 1996; Wehrenberg, 1996), so that vertical migration would produce differences in zoeal densities between flood and ebb tide. Numerous field and laboratory studies conducted with brachyuran zoeae have demonstrated complex behavioural responses to external factors and internal rhythms involved in vertical migration (Cronin and Forward, 1979; Sulkin, 1973; Sulkin, 1984). Migration to the surface during ebb tide would lead to export from the estuary. The idea of active dispersal is supported by the comparison of distribution of brachyuran zoeae with tracers of mangrove influence as water temperature, salinity, and ${ }^{13} \mathrm{C}$ of particulate organic matter (Schwamborn, 1997). While water mass analysis and ${ }^{13} \mathrm{C}$ of POM indicate a sharp front between the estuarine plume and nearshore waters, some brachyuran zoeae seem to perform ontogenetic migrations between those water masses. The spatial distribution observed at IES is probably the consequence of both processes (loss to the zoeal population and active vertical migration).

Our data show that accumulation of brachyuran zoeae occurs in the estuarine plumes, while only few individuals cross the coastal front and are advected to the continental shelf, probably by active dispersal mechanisms. The decrease in larval abundance from ebb to subsequent flood tides observed in the study area (Wehrenberg 1996) and at several similar estuarine inlets (Brookins and Epifanio 1985; Wehrtmann and Dittel, 1990; Dittel et al. 1991; DeVries et al. 1994; Schwamborn and Bonecker 1996; Freire, 1998) may not be due to export to the shelf only, but may be related to processes (e.g. predation mortality) occurring inside the estuarine plumes.

\section{ACKNOWLEDGEMENTS}

Thanks to G. Hempel, K. Anger, C. von Dorrien, S. H. L. Schwamborn and W. Wiedemeyer for support and helpful comments. The authors thank P. A. Coelho and P. A. Coelho Jr. for the identification of the ovigerous females. Special thanks also to the crew members of RV Victor Hensen. This study was financed by the German Federal Minister for Education, Science, Research and Technology (project numbers 0339607A and 03F0144A). The Brazilian environment agency IBAMA provided logistical support at Itamaracá. Infrastructure for laboratory work in Recife was provided by the Departamento de Oceanografia, Universidade Federal de Pernambuco in Recife, Brazil.

\section{REFERENCES}

ANGER, K.; MONTÚ, M..; BAKKER, C.; FERNANDES, L. L. Larval development of Uca thayeri Rathbun, 1900 (Decapoda: Ocypodidae) reared in the laboratory. Meeresforsch. v. 32, p. 276-294, 1990 .

Tropical Oceanography, Recife, v. 29, n. 1, p. 1-18, 2001. 
ANGER, K.; SPIVAK, E. D.; BAS, C.; ISMAEL, D.; LUPPI, T. Hatching rhythms and dispersion of decapod crustacean larvae in a brackish coastal lagoon in Argentina. Helgoländer Meeresunters. v. 48, p. 445-466, 1994.

BACARDIT, R. Larvas de Crustacea de Decapoda del Atlantico Sudoccidental I: Primer estudo del genero Parapagurus Smith (Anomura, Parapaguridae). Physis, v. 43, p. 73-77, 1985a.

BACARDIT, R. Larvas de Crustacea Decapoda del Atlantico Sudoccidental II: Morfologia de las Larvas y Postlarvas de Eurypodius latreillei Guerin (Brachyura, Majidae), provenientes de plancton del Mar Argentino. Physis, v. 43, p. 79-89, 1985 b.

BAKKER, C.; MONTÚ, M.; ANGER, K.; HARMS, J. Larval development of a tropical spider crab, Libinia ferreirae, Brito Capello, 1871 (Decapoda: Majidae), reared in the laboratory. Meeresforsch., v. 33, p. 90-103, 1990.

BERGIN, M. E. Hatching rythms in Uca pugilator (Decapoda: Brachyura). Mar. Biol., v. 63, p. 151$158,1981$.

BÖRNER, R. Fischereibiologische Untersuchungen an den Fischbeständen des "Canal de Santa Cruz", Pernambuco, Brasilien. Bremen, 1994. 75p. M.Sc. Thesis, University of Bremen, Germany.

BOSCHI, E. E.; SCELZO, M. A. Larval development of the spider crab Libinia spinosa H. Milne Edwards, reared in the laboratory (Brachyura, Majidae). Crustaceana Suppl., v. 2, p. 171-180, 1968.

BROSSI-GARCIA, A. L.; RODRIGUES, M. D. Zoeal morphology of Pachygrapsus gracilis (Saussure, 1858) (Decapoda, Grapsidae) reared in the laboratory. Invertebrate Reproduction and Development, v. 24, p. 197-204, 1993.

BROOKINS, K. G.; EPIFANIO, C. E. Abundance of brachyuran larvae in a small coastal inlet over six consecutive tidal cycles. Estuaries, v. 8, p. 60-67, 1985

CHEN, Y.-H.; SHAW, P.-T.; WOLCOTT, T. G. Enhancing estuarine retention of planktonic larvae by tidal currents. Estuar. Coast. Shelf Sci., v. 45, p. 525-533, 1997.

CHRISTY, J. H. Adaptive significance of semilunar cycles of larval release in fiddler crabs (Genus $U c a$ ): Test of an hypothesis. Biol. Bull., v. 163, p. 251-263, 1982.

CLARKE, K. R.; WARWICK, R. M. Change in marine communities: An approach to statistical analysis and interpretation. Plymouth: Natural Environmental Research Council, 1994. 144 p.

COSTLOW, J. D.; BOOKHOUT, C. G. The complete larval development of the land crab, Cardisoma guanhumi Latreille in the laboratory (Brachyura, Gecarcinidae). Crustaceana Suppl., v. 2, p. 259-270, 1968.

CRONIN, T. W.; FORWARD, R. B. Tidal Vertical Migration: an endogenous rythm in estuarine Crab Larvae. Science, v. 205, p. 1020-1022, 1979.

DEVRIES, M. C.; TANKERSLEY, R. A.; FORWARD, R. B. JR.; KIRBY-SMITH, W. W., LUETTICH, R. A. Jr. Abundance of estuarine crab larvae is associated with tidal hydrologic variables. Mar. Biol., v. 118, p. 403-413, 1994. 
DIAZ, H.; EWALD, J. J. A comparison of the larval development of Metasesarma rubripes (Rathbun) and Sesarma ricordi $\mathrm{H}$. Milne Edwards (Brachyura, Grapsidae) reared under similar laboratory conditions. Crustaceana Suppl., v. 2, p. 225-248, 1968.

DIAZ, H.; COSTLOW, J. D. Larval development of Ocypode quadrata (Brachyura: Crustacea) under laboratory conditions. Mar. Biol., v. 15, p. 120-131, 1972.

DIAZ, H.; BEVILAQUA, M. Early developmental sequences of Aratus pisonii (H. Milne-Edwards) (Brachyura, Grapsidae) under laboratory conditions. J. Coastal Res., v. 3, p. 63-70, 1987.

DITTEL, A. I.; EPIFANIO, C. E. Seasonal and tidal abundance of crab larvae in a tropical mangrove system, Gulf of Nicoya, Costa Rica. Mar. Ecol. Prog. Ser,. v. 65, p., 25-34, 1990.

DITTEL, A. I.; EPIFANIO, C. E.; LIZANO, O. Flux of crab larvae in a mangrove creek in the Gulf of Nicoya, Costa Rica. Estuar. Coast. Shelf Sci., v. 32, p. 129-140, 1991.

DOMINGUES, M. R.; HEBLING, N. J. Ucides cordatus (Linn., 1763) (Crustacea, Decapoda). Complete larval development under laboratory conditions and its systematic position. Revta. Bras. Zool., v. 6, n. 1, p. 147-166, 1989.

EGGLESTON, D. B.; ARMSTRONG, D. A.; ELIS, W. A.; PATTON, W. S. Estuarine fronts as conduits for larval transport: hydrodynamics and spatial distribution of Dungeness crab larvae. Mar. Ecol. Prog. Ser., v. 164, p. 73-82, 1998.

EWING, G. Slicks, surface films and internal waves. J. Mar. Res., v. 9, p. 161-187, 1950.

FRANSOZO, A., HEBLING, N. J. Desenvolvimento larval de Sesarma rectum Randall, 1840 (Decapoda, Grapsidae), em laboratório. Revta. Bras. Biol., v. 46, p. 353-364, 1986.

FREIRE, A. S. Dispersão larval do caranguejo do mangue Ucides cordatus (L. 1763) em manguezais da Baía de Paranaguá, Paraná. Ph.D. thesis, Universidade de São Paulo, 1998, 66f.

GUERAO, G.; CUESTA, J. A.; ABELLÓ, P.; GONZALES-GORDILLO, J. I. Larval development of Brachynotus gemmelari (Rizza, 1839) (Brachyura, Grapsidae) reared under laboratory conditions. J. Plankton Res., v. 17, p. 1143-1161, 1995.

HERRNKIND, W. F. The Breeding of Uca pugilator (Bosc) and mass rearing of the larvae with comments on the behaviour of the larval and early crab stages (Brachyura, Ocypodidae). Crustaceana Suppl., v. 2, p. 214-224, 1968.

JILLET, J. B.; ZELDIS, J. R. Aerial observations of surface patchiness of a planktonic crustacean. Bull. Mar. Sci., v. 37, p. 609-619, 1985

KINGSFORD, M. J.; CHOAT, J. H. Influence of surface slicks on the distribution and onshore movements of small fish. Mar. Biol., v. 91, p. 161-171, 1986.

KURATA, H. Studies on the life histories of decapod crustacea of Georgia.Goergia: Univ. of Georgia Marine Institute, 1970. Part III: Larvae of decapod crustacea of Georgia (Final Report), 274 p.

MONTÚ, M.; BAKKER, C.; LOUREIRO FERNANDES, L. Desarrollo larval de Pilumnus reticulatus Stimoson, 1860 (Decapoda, Brachyura, Xanthidae) criada en laboratorio. Neritica, v. 4, p. 169-190, 1989.

Tropical Oceanography, Recife, v. 29, n. 1, p. 1-18, 2001. 
MONTÚ, M.; ANGER, K.; BAKKER, C. Variability in the larval development of Metasesarma rubripes (Decapoda, Grapsidae) reared in the laboratory. Nerítica, v. 5, p. 113-128, 1990.

MORGAN, S. G. Impact of planctivorous fishes on dispersal, hatching, and morphology of estuarine crab larvae. Ecology, v. 71, p. 1639-1652, 1990.

NEGREIROS-FRANSOZO, M. L. Desenvolvimento pós-embrionário de Panopeus americanus Saussure, 1857 (Decapoda, Xanthidae), em laboratório. Rev. Brasil. Biol., v. 46, n. 1, p. 173-188, 1986.

NEGREIROS-FRANZOZO, M. L.; FRANZOZO, A.; HEBLING, N. J. Larval development of Persephona mediterranea (Herbst, 1794) (Brachyura, Leucosiidae) under laboratory conditions. Crustaceana, v. 57, p. 177-193, 1989.

NEUMANN-LEITÃO, S. Resenha literária sobre zooplâncton estuarino no Brasil. Trab. Oceanogr. Univ. Fed. PE., Recife: v. 23, p. 25-53, 1995

NEUMANN-LEITÃO, S.; GUSMAO, L. M. O.; SILVA, T. A.; NASCIMENTO-VIEIRA, D. A. Variação diurna e sazonal do microzooplâncton no estuário do Rio Paripe-PE-Brasil. Arq. Biol. Tecnol., v. 39, n. 2, p. 373-384, 1996.

NEUMANN-LEITÃO, S.; SCHWAMBORN, R. Interações tróficas no Canal de Santa Cruz. In: BARROS, H. M.; ESKINAZI-LEÇA, E.; MACEDO, S. J., LIMA, T.(eds.) Gerenciamento participativo de estuários e manguezais. Ed. Universitária UFPE, Recife, p.163-180, 2000.

NEW, A. L.; DYER, K. R. On the generation of lateral internal waves by a surface seiche in a partially mixed estuary Estuar. Coast. Shelf Sci, v. 24, p. 557-566, 1987.

NEW, A. L.; DYER, K. R.; LEWIS, R. E. Predictions of the generation and propagation of internal waves and mixing in a partially stratified estuary. Estuar. Coast. Shelf. Sci., v. 22, p. 199-214, 1986.

PARANAGUÁ, M. N.; ESKINAZI-LEÇA, E. Ecology of a nothern tropical estuary in Brazil and technological perspectives in fishculture. In: Yanez-Arincibia, A. (ed.). Fish community ecology in estuarine and coastal lagoons: Towards an ecosystem integration. Mexico: UNAM, 1985. p. 595-614. PAULA, J. The first zoeal stages of Polybius henslowi Leach, Maja squinado (Herbst), Pachygrapsus marmoratus (Fabricius), and Uca tangeri (Eydoux) (Crustacea, Decapoda, Brachyura). Arq. Mus. Bocage, v. 2, p. 137-147, 1985.

PAULA, J. A key and bibliography for the identification of zoeal stages of brachyuran crabs (Crustacea, Brachyura) from the Atlantic coast of Europe. J. Plankton Res., v. 18, p. 17-27, 1996.

PIÑEDA, J. Predictable upwelling and the shoreward transport of planctonic larvae by internal bores. Science, v. 253, p. 548-551, 1991.

RICE, A. L. Crab zoeal morphology and its bearing on the classification of the Brachyura. Trans. Zool. Soc., v. 35, p. 271-424, 1980.

RIEGER, P. J.; HEBLING, N. J. Desenvolvimento larval de Hepatus pudibundus (Herbst, 1785) (Decapoda, Calappidae), em laboratorio. Rev. Brasil. Biol., v. 53, n. 4, p. 513-528, 1993.

Tropical Oceanography, Recife, v. 29, n. 1, p. 1-18, 2001. 
ROBERTSON, A. I.; ALONGI, D. M. (ed.). Coastal and Estuarine Studies: Tropical mangrove ecosystems. Washington: American Geophysical Union, 1992, v. 41, 1992.

ROBERTSON, A. I.; BLABER, S. J. M. Plankton, epibenthos, and fish communities. In: ROBERTSON, A. I.; ALONGI, D. M. (ed.). Coastal and Estuarine Studies: Tropical mangrove ecosystems. Washington: American Geophysical Union, 1992, v. 41, p.173-224.

RODRIGUEZ, A.; GONZALEZ-GORDILLO, J. I.; CUESTA, J. A. Larval stages of Brachynotus atlanticus Forest, 1957 (Crustacea: Decapoda: Grapsidae) reared under labratory conditions J. Plankton Res., v. 14, n. 6, p. 867-883, 1992.

RUSSEL, F. S.; COLMAN, J. S. The zooplankton I: Gear, methods and station lists. Great Barrier Reef Exped. Sci. Rep., v. 2, n. 2, p. 5-36, 1931.

SCHWAMBORN, R.; BONECKER, A. C. T. Seasonal changes in the transport and distribution of meroplankton into a Brazilian estuary with emphasis on the importance of floating mangrove leaves. Arq. Biol. Tecnol., v. 39, p. 451-462, 1996.

SCHWAMBORN, R.; SAINT-PAUL, U. Mangroves - Forgotten forests? Natural Resources and Development, v. 43/44, p. 13-36, 1996.

SCHWAMBORN, R. Influence of mangroves on community structure and nutrition of zooplankton in Northeast Brazil. Bremen, 1997. 77f. Tese de Doutorado, Universidade de BremenAlemanha.

SCHWAMBORN, R.; EKAU, W.; PINTO, A. S.; SILVA, T. A.; SAINT-PAUL, U. The contribution of estuarine decapod larvae to marine macrozooplankton communities in northeast Brazil. Arch. Fish. Mar. Res., v. 47, p. 167-182, 1999.

SCHWAMBORN, R.; NEUMANN-LEITÃO, S. Trophodynamics of the Itamaracá estuarine system, Brazil - Current knowledge and ongoing studies. In: Abstracts of the international conference: Sustainable use of estuaries and mangroves: Challenges and perspectives. Recife, 2000. Conference held in Recife, Brazil from 22 to 28 May 2000.

SHANKS, A. L. Surface slicks associated with tidaly forced internal waves may transport pelagic larvae of benthic invertebrates and fishes shoreward. Mar. Ecol. Prog. Ser., v. 13, p. 311-315, 1983.

SHANKS, A. L. Behavioral basis of internal-wave-induced shoreward transport of megalopae of the crab Pachygrapsus crassipes. Mar. Ecol. Prog. Ser. v. 24, p. 289-295, 1985.

STEIFF, B. Ein Bestimmungsschlüssel für die Larvenstadien der Brachyuren in der Deutschen Bucht. Ber. Biol. Anst. Helgoland, v. 5, p. 1-40, 1990.

SULKIN, S. D. Depth regulation of crab larvae in the absence of light. J. Exp. Mar. Biol. Ecol., v. 13, p. 73-82, 1973.

SULKIN, S. D. Review: Behavioral basis of depth regulation in the larvae of brachyuran crabs. Mar. Ecol. Prog. Ser. v. 15, p. 181-205, 1984.

TORBOHM-ALBRECHT, S. Dekapodenlarven im Plankton des Canal de Santa Cruz, Pernambuco, Brasilien. Bremen, 1995. 89 p. Tese (Mestrado) - Universidade de Bremen-Alemanha.

Tropical Oceanography, Recife, v. 29, n. 1, p. 1-18, 2001. 
VASCONCELOS FILHO, A. L.. Estudo ecológico da região de Itamaracá, Pernambuco, Brasil. IV. Alimentação da Sardinha Bandeira, Opisthonema oglinum (Le Sueur, 1817), no Canal de Santa Cruz. Trab. Oceanogr. Univ. Fed. PE, Recife: v. 14, p. 105-116, 1979.

VASCONCELOS FILHO, A. L.. Aspectos gerais sobre a alimentação do Carapicu, Eucinostomus spp. (Pisces-Gerreidae), no Canal de Santa Cruz-Pernambuco. Rev. Nordest. Biol. v. 3, p. 101-110, 1980.

VASCONCELOS FILHO, A. L.; GUEDES, D. de S.; GALIZA, E. M. B.; AZEVEDO-ARAUJO, S. Estudo ecológico da região de Itamaracá-Pernambuco-Brasil. XXVII. Hábitos alimentares de alguns peixes estuarinos. Trab. Oceanogr. Univ. Fed. PE, Recife: v. 18, p. 231-260, 1984.

WARNER, G. F. The larval development of the mangrove tree crab, Aratus pisonii, (H. Milne Edwards), reared in the laboratory (Brachyura, Grapsidae). Crustaceana Suppl. v. 2, p. 249-258, 1968.

WEHRENBERG, T. Zum Einfluss von Tageszeit und Gezeiten auf Zusammensetzung und Transport des Makrozooplanktons in den Mündungs-Bereichen des Mangrovenästuars "Canal de Santa Cruz", Pernambuco, Brasilien. Bremen, 1996. 105 p. Tese de Mestrado, Universidade de Bremen-Alemanha. 105 pp.

WEHRTMANN, I. S.; DITTEL, A. I. Utilization of floating mangrove leaves as a transport mechanism of estuarine organisms, with emphasis on the decapod crustacea. Mar. Ecol. Prog. Ser., v. 60, p. 67-73, 1990.

WILLEMS, K. A. Larval development of the land crab Gecarcinus lateralis (Freminville, 1835) (Brachyura: Gecarcinidae) reared in the laboratory. J. Crust. Biol., v. 2, p. 180-201, 1982.

WOLCOTT, T. G.; WOLCOTT, D. L. Larval loss and spawning behavior in the land crab Gecarcinus lateralis (Freminville). J. Crust. Biol., v. 2, p. 477-485, 1982.

ZAR, J. Biostatistical analysis, 3rd edn. Prentice-Hall, Englewood Cliffs, New Jersey, 1996. ZELDIS, J. R., JILLET, J. B. Aggregation of pelagic Munida gregaria (Fabricius) (Decapoda, Anomura) by coastal fronts and internal waves. J. Plankton Res., v. 4, p. 839-857, 1982. 